\title{
OS LIMITES DO PRINCÍPIO DA PRECAUÇÃO NAS DECISÕES JUDICIAIS BRASILEIRAS EM MATÉRIA AMBIENTAL
}

\section{Carina Costa de Oliveira}

\begin{abstract}
Professora de direito internacional e de direito ambiental na Universidade de Brasília (UnB), Brasília, DF, Brasil. Pós-doutora pela Universityof Cambridge - Cambridge Centre for Environment, Energy and Natural ResourceGovernance (CEENRG), com bolsa da CAPES-Programas Estratégicos; e pela Law School - Universityof Adelaide, Austrália, com bolsa da FAP-DF. Doutora em Direito pela Universidade de Paris II, Panthéon-Assas. Mestre em direito internacional no Centro Universitário de Brasília - UNUCEUB, Brasília-DF, Brasil. Email: carinaoliveira@unb.br
\end{abstract}

Fabrício Ramos Ferreira

Professor da graduação do Centro Universitário IESB (IESB), Brasília-DF, Brasil. Doutorando em Direito pela Universidade de Brasília (UnB), Brasília-DF, Brasil. Mestre em Desenvolvimento Sustentável pelo Centro de Desenvolvimento Sustentável da Universidade de Brasília (CDS/UnB), Brasília-DF, Brasil. Especialista em Direito Ambiental e Desenvolvimento Sustentávelpelo Centro de Desenvolvimento Sustentável da Universidade de Brasília (CDS/UnB), Brasília-DF, Brasil. Graduado em Direito pela Universidade da Amazônia (UNAMA), Belém-PA, Brasil. Email: ferreira.fabricio@uol.com.br

\section{Gabriela Garcia Batista Lima Moraes}

Professora da Faculdade de Direito da Universidade de Brasília (UnB). Doutora em Direito pela Universidade de Aix-Marseille-França e pelo Centro Universitário de Brasília (Uniceub), Brasília - DF, Brasil. Mestre em Direito pelo Centro Universitário de Brasília (Uniceub), Brasília - DF, Brasil. Especialista em Direito Internacional Ambiental pela UNITAR-UNEP, Suíça. Bacharel em Direito pelo Centro Universitário de Brasília (Uniceub), Brasília - DF, Brasil. Email: gabrielalima@unb.br

Igor da Silva Barbosa

Diplomata no Ministério das Relações Exteriores do Brasil, Brasília - DF, Brasil. Graduado em Direito pela Universidade Federal da Bahia (UFBA), Salvador - BA, Brasil. Graduado em Diplomacia pelo Instituto Rio Branco, Brasília-DF, Brasil. Email: igorbarbosa1804@gmail.com

\section{RESUMO}

O objeto do trabalho éa análise dos limites dos efeitos materiais e processuais do princípio da precaução, analisando-o diretamente nas decisões judiciais brasileiras. Desta forma, foram coletados os acórdãos disponíveis dos bancos de dados informatizados de vários Tribunais brasileiros, que em seu sistema, apresentaram uma resposta positiva ao termo "princípio da precaução". Chegou-se a um número final de 182 acórdãos, que foram organizados por grandes temas. Foi então possível analisar a influência do princípio nas autorizações administrativas das decisões potencialmente poluidoras, na justificativa para a inversão do ônus da prova, chegando-se a 
conclusão final de que o mesmo é implementado de forma inapropriada nas decisões judiciais. O motivo é devido às suas bases conceituais imprecisas, bem como dada a ausência de critérios para a aplicação do princípio em um caso concreto. Ao final, foram sintetizados os critérios que poderiam ser aplicados pelas autoridades administrativas e pelos juízes na interpretação do princípio

Palavras chave: princípio da precaução; efeitos; limites; critérios; decisões judiciais ambientais.

The limits of the precautionary principle in brazilian environmental judicial decisions

\section{ABSTRACT}

The object of the work is the analysis of the limits of the material and procedural effects of the precautionary principle, analyzing it directly into the Brazilian court decisions. For this purpose, were collected the judgments available in the databases of several Brazillian Courts, which showed a positive response to the term "precautionary principle". Were analyzed a total of 182 judgments, which were organized by big themes. So, it was possible to analyse the influence or the principle in administrative decisions that grant polluting permits, on the reason for the shift of burden of proof, reaching the conclusion that it is implemented inappropriately by the courts. The reason is in the inaccurate conceptual bases, as well in the absence of a criteria for the application of the principle in a concrete case. In the end, have been synthesized the criteria that could be applied by the administrative authorities and by the judges in the intepretation of the principle.

Keywords: precautionary principle; effects; limits; criteria; environmental judicial decisions. 


\section{Introdução}

O princípio da precaução tem um impacto evidente na prevenção e na reparação de danos ambientais. Há uma contribuição evidente na prevenção de danos ambientais, por exemplo, pois as autoridades públicas podem, por efeito do princípio, proibir ou suspender atividades potencialmente poluidoras. Todavia, a intepretação precisa e adequada do princípio pelos tribunais ainda não é recorrente em razão de bases conceituais ainda imprecisas, o que decorre da falta de critérios para a sua utilização ou no seu manejo como forma de imposição ideológica. Nesse sentido, antes de demonstrar os limites interpretação do princípio, apresentar-se-á brevemente a previsão normativa e jurisprudencial no Brasil.

No Brasil, em matéria de direito ambiental, o princípio se evidencia em várias normas infraconstitucionais, especificamente, no Decreto de 2004 sobre a zona costeira ${ }^{1}$, na lei que prevê as regras para a gestão dos organismos geneticamente modificados de $2005^{2}$, na Política Nacional sobre as Mudanças Climáticas de $2009^{3}$ e na Política Nacional de Resíduos Sólidos de 20104. O princípio está implicitamente inserido na Constituição Federal, no artigo 225, parágrafo primeiro, alínea V, nos seguintes termos:

"Art. 225. Todos têm direito ao meio ambiente ecologicamente equilibrado, bem de uso comum do povo e essencial à sadia qualidade de vida, impondo-se ao Poder Público e à coletividade o dever de defendê-lo e preservá-lo para as presentes e futuras gerações. $\S 1^{\circ}$ Para assegurar a efetividade desse direito, incumbe ao Poder Público: [...] V - controlar a produção, a comercialização e o emprego de técnicas, métodos e substâncias que comportem risco para a vida, a qualidade de vida e o meio ambiente ${ }^{5}$.

Considerando que o texto se refere à obrigação do poder público de agir sempre que houver um risco, é possível identificar uma

1 Artigo $5^{\circ}$, X, do Decreto federal brasileiro ${ }^{\circ} 5.300$ de 7 de dezembro de 2004, que regulamenta a Lei $\mathrm{n}^{\circ}$ 7.661, de 14 de maio de 1988, que institui o Plano Nacional de Gestão Costeira.

2 Art. $^{\circ}$ da Lei federal brasileira $\mathrm{n}^{\circ} 11.105$ de 24.03.2005 que estabelece normas de segurança e de controle das atividades ligadas aos organismos geneticamente modificados.

3 Art. $3^{\circ}$ da Lei federal brasileira ${ }^{\circ} 12.187$ de 29.12.2009, a Política Nacional das Mudanças Climáticas.

4 Art. $6^{\circ}$, I, da Lei federal brasileira n ${ }^{\circ} 12.305$ de 2.08.2010, a Política Nacional de Resíduos Sólidos. 5 Constituição Federal de 1988. 
aplicação implícita do princípio da precaução. Mesmo que esta previsão não seja explícita, as normas infraconstitucionais contribuem para a sua implementação. Os mais diversos Tribunais brasileiros têm se manifestado, por meio da sua jurisprudência desde os anos 2000, sobre a aplicação do princípio, por exemplo, nos casos da soja geneticamente modificada $^{6}$, de plantas bioinseticida ${ }^{7}$, dos campos eletromagnéticos ${ }^{8}$, da construção de barragens ${ }^{9}$, de carcinicultura ${ }^{10}$, de resíduos sólidos ${ }^{11}$, agrotóxicos $^{12}$, amianto $^{13}$ e de derramamentos de petróleo ${ }^{14}$.Em 2016, o princípio da precaução foi reconhecido expressamente como um princípio constitucional no RE $627.189 / \mathrm{SP}^{15}$. O Acórdão ${ }^{16}$ consagrou o princípio da precaução como um princípio constitucional conectado ao Artigo 225, parágrafo $1^{\circ}$., incisos IV e V. A decisão afirma que essa consagração já tinha sido iniciada em precedentes da Corte desde $2008^{17}$, ou seja, há uma consolidação baseada em precedentes que iniciaram o debate sobre o caráter constitucional do princípio.

Um efeito evidente do princípio é verificado nas decisões relacionadas à responsabilidade civil por dano ambiental (HAUTEREAUBOUTONNET, 2005).É possível constatar a influência do princípio, por exemplo, na flexibilidade do nexo de causalidade ${ }^{18}$ pelo efeito da inversão do ônus da prova ${ }^{19}$. Com relação ao elemento "culpa", em matéria de 6 TRF $1^{a}$ Região, Apelação civel n ${ }^{\circ}$ 2000.01.00.014661-1/DF, decisão de 8 de agosto de 2000.

7 TRF $1^{\text {a }}$ Região, Apelação civel n²001.34.00.010329-1/DF, decisão de 12 de fevereiro de 2004; STJ, Agravo regimental na Medida Cautelar. n.14.446/ RS, decisão de 21 de outubro de 2008.

8 STF, Recurso Extraordinárion. 627189/SP, Relator Ministro Dias Toffoli. Decisão 8 de junho de 2016; STF, Repercussão geral no Recurso Extraordinário. n ${ }^{\circ} 627.189$ SP/2011, decisão de 22 de setembro de 2011; STJ, Agravo Regimental na Medida Cautelar n. 17.449/ RJ, decisão de 22 de setembro de 2011.

9 STJ, Recurso Especial n.1330027/ SP, decisão de 11 de junho de 2012.

10 TRF $1^{\mathrm{a}}$ Região, Apelação cível $\mathrm{n}^{\mathrm{o}}$ 0006530-49.2001.4.01.4000/PI, decisão de 16 de dezembro de 2013.

11 STF, Arguição de Descumprimento de Preceito Fundamentaln ${ }^{\circ}$ 101/DF, decisão de 24 de junho de 2009.

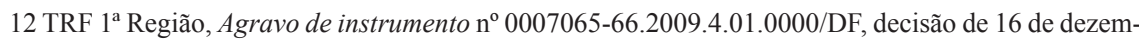
bro de 2013.

13 STF, Medida Cautelar na Arguição de descumprimento de Preceito Fundamentalnº 234/DF, decisão de 28 de setembro de 2011.

14 TRF 2a Região, Agravo de instrumento n. 0004075-70.2012.4.02.0000, decisão de 31 de julho de 2012.

15 STF, Recurso Extraordinárion. 627189/SP, Relator Ministro Dias Toffoli. Decisão 8 de junho de 2016.

16 Páginas 20, 21 do Acórdão do Recurso extraordinário n. 627189/SP, 2016.

17 STF, ADI n. 3510 de 2008; STF, ADPF n. 101/DF, e STF ACO n. 876 MC-AgR.

18 STJ, Recurso especial n. 769.753/SC, decisão de 08 de setembro de 2009.

19 STJ, Recurso especial n. 1.330.027/SP, decisão de 11 de junho de 2012; TRF 2a Região, Agravo de 
direito ambiental, não é necessário demonstrá-la, pois a responsabilidade é objetiva. Por esse motivo, não há influência do princípio na interpretação da culpabilidade. Quanto ao dano (ou a potencialidade de dano) e ao nexo de causalidade, ambos devem ser demonstrados no caso de danos ambientais (LEITE; AYALA, 2014).

O princípio da precaução aporta uma função tanto preventiva quanto reparatória no direito ambiental. Nos dois casos, o princípio orienta a intervenção do poder público em caso de provas concretas de riscos graves e irreversíveis. No que concerne à prevenção ${ }^{20}$, o princípio fundamenta medidas que podem incluir restrições temporárias, anulações de autorizaçõe ${ }^{21}$ e o compromisso com a continuação das pesquisas técnicas ou científicas sobre a matéria. $\mathrm{O}$ papel reparatório do princípio também pode ser observado nas hipóteses em que é determinada a inversão do ônus da prova. Esses dois efeitos, quais sejam, a orientação do poder público bem como a possibilidade de inversão do ônus da prova, podem ser classificados como efeitos processuais e, de modo geral, considerados como as fundamentais contribuições do princípio da precaução decorrentes das interpretações dos tribunais nacionais. Essa constatação tem como fundamento a análise detida e cautelosa das decisões nacionais dos tribunais superiores, bem como a análise comparada e internacional do tema, análise essa que demonstrou a importância do juiz na delimitação e na operacionalização do princípio da precaução.

Todavia, a implementação do princípio possui limites relacionados às bases conceituais imprecisas utilizadas pelos tribunais brasileiros. Por vezes, o princípio é visto como uma regra que pode, sem nenhum critério objetivo, ser aplicada ${ }^{22}$. Não há uma interpretação no sentido de garantir o equilíbrio entre interesses presentes. Isso pode ser constatado, pois as decisões não indicam quais foram critérios utilizados para a aplicação

instrumento n. 0004075-70.2012.4.02.0000, decisão de 31 de julho de 2012; STJ, Recurso especial $\mathrm{n}$. 883.656/RS, decisão de 9 de março de 2010; STJ, Recurso especial n. 972.902/RS (2007/0175882-0), decisão de 25 de agosto de 2009; STJ, Recurso especial n. 1.237.893/SP, decisão de 24de setembro de 2013.

20 STJ, Recurso especial n. 592.682/RS, decisão de 6 de dezembro de 2005; STJ, Recurso especial n.1.172.553/PR,decisão de 27 de maio de 2014.

21 TRF $1^{\text {a }}$ Região, Apelação cível n. 2001.34.00.010329-1/DF, decisão de 12 de fevereiro de 2004.

22 STJ, Agravo Regimental na Suspensão de Liminar e Sentença 1279/PR, decisão de 16 de março de 2011; STJ, Agravo Regimental no Agravo em Recurso Especial n.431420/MG, decisão de 6 de fevereiro de 2014; STJ, Recurso especial n. 1.115.555/MG, decisão de 15 de fevereiro de 2011; TRF $1^{\mathrm{a}}$ Região, Apelação cível n. 0000663-24.2009.4.01.3603/MT, decisão de 15 de fevereiro de 2016; TRF $1^{\text {a }}$ Região, Apelação civel n. 0003234-29.2009.4.01.4100/RO, decisão de 25 de janeiro de 2016, entre outros. Foram identificados mais de 80 acórdãos que invocaram o princípio na ementa ou na redação do voto, sem que fosse utilizado qualquer critério objetivo para a sua aplicação. 
ou não do princípio no caso concreto $^{23}$ (NOIVILLE, 2006). Decorre desse contexto, a importância de analisar a interpretação do princípio da precaução pelos tribunais brasileiros (1), uma utilização, todavia, limitada pelas imprecisões ligadas às bases conceituais pouco claras do princípio (2).

\section{A interpretação do princípio da precaução pelos tribunais brasileiros}

Para que se pudesse fazer uma análise ${ }^{24}$ da interpretação do princípio da precaução, foram coletados os acórdãos disponíveis nos bancos de dados informatizados de vários Tribunais Brasileiros ${ }^{25}$ que em seus sistemas de jurisprudência apresentaram uma resposta positiva ${ }^{26}$ ao termo "princípio da precaução"27. A escolha do espaço amostral, que se caracteriza por julgados prioritariamente provenientes de tribunais federais, deu-se em razão da necessidade de delimitação do campo de pesquisa, pelo seu sistema informatizado de jurisprudência ${ }^{28}$ e pela abrangência dos temas ambientais.

A análise dos julgados dos Tribunais Superiores deu-se em razão da finalidade própria do recurso especial de "manter a uniformidade da lei federal, ou seja, velar para que esta seja interpretada de maneira idêntica em qualquer Estado da Federação ou por qualquer órgão do Poder Judiciário." (NEGRÃO, 1997, p. 05), bem como do recurso extraordinário que tem por finalidade corrigir eventual "ofensa direta e frontal à Constituição Federal e repercussão geral das questões constitucionais.” (MORAES, 2014, p. 604).

23 Para que haja um nível apropriado de proteção para o meio ambiente, alguns critérios poderiam ser utilizados: probabilidade de ocorrência do dano, tolerabilidade do dano, amplitude das consequências nocivas do dano, decisão fundamentada em expertises, análise das tecnologias alternativas ou disponíveis, adequação às normas tecnicas, proporcionalidade entre as vantagens e inconvenientes da atividade.

24 Algumas análises jurisprudenciais acerca da aplicação do princípio da precaução já foram feitas, sem contudo, efetuar uma varredura mais profunda dos julgados, analisando-os quantitativa e qualitati vamente(ANTUNES, 2007; CZYZESKI, 2010).

25 Tribunais Regionais Federais da $1^{\mathrm{a}}, 2^{\mathrm{a}}, 3^{\mathrm{a}}, 4^{\mathrm{a}}$, e $5^{\mathrm{a}}$ Regiões (TRF $1^{\mathrm{a}}$ Região, TRF $2^{\mathrm{a}}$ Região, TRF $3^{a}$ Região, TRF 4 ${ }^{a}$ Região, TRF 5a Região), Superior Tribunal de Justiça (STJ) e Supremo Tribunal Federal (STF).

26 Considerou-se resposta positiva, a identificação do acórdão que contenha, seja em sua ementa e/ou em seu voto, a referencia expressa ao termo "princípio da precaução".

27 O resumo dos dados compilados podem ser consultados no anexo.

28 A ausência de um sistema informatizado em alguns tribunais estaduais, a imprecisão destes ou a dificuldade na leitura dos relatórios e votos, fez com que, genericamente, estas cortes fossem excluídas do espaço amostral selecionado. 
Inicialmente, considerando-se todo o universo de pesquisa, foram identificados mais de 450 acórdãos que responderam positivamente ao critério definido. Deste total, foram eliminados os julgados que não possuíam vínculo com o Direito Ambiental ${ }^{29}$, chegando-se a um número final de 182 (cento e oitenta e dois) acórdãos ${ }^{30}$, que foram organizados por grandes temas ${ }^{31}$, tais como: fauna e flora, mineração, unidades de conservação, entre outros. Os acórdãos também foram separados segundo um critério de "correta aplicação"32 do princípio da precaução. Os dados foram tabulados em uma planilha de Exel, para que fosse possível a interrelação dos mesmos.

A pesquisa tentou abranger o maior número possível de acórdãos, compreendendo, então, uma janela temporal dos anos de 2007 a 2016. Desta forma, foi possível concluir que os tribunais brasileiros interpretam o princípio da precaução de uma maneira preventiva e reparatória, uma vez que, $43 \%$ dos acórdãos foram identificados como não tendo aplicado de forma correta o princípio da precaução, ou seja, ou o invocaram de forma ideológica, para justificar uma posição pessoal do julgador, ou não fizeram uma análise dos fatos para, apontando a existência de incerteza científica ou outros critérios objetivos, justificar a sua utilização.

Um dado que chamou a atenção dos pesquisadores foi que $57 \%$ dos acórdãos foram classificados como não tendo aplicado o princípio da precaução de forma correta ${ }^{33}$. Dentro deste universo, $41 \%$ deles foram proferidos em julgados sem que houvesse uma análise de mérito ${ }^{34}$.Ou seja, pode-se dizer que está sendo construída uma jurisprudência de bases

29 Por exemplo: TRF $1{ }^{\text {a }}$ Região, Apelação civel n. 0006321-57.2003.4.01.3500/GO, decisão de 26 de fevereiro de 2016; TRF $1{ }^{\text {a }}$ Região, Apelação em mandado de segurança n. 0043939-06.2007.4.01.3400/ DF, decisão de 24 de novembro de 2015.

3006 acórdãos são provenientes do STF ou o equivalente a 3\% do total de acórdãos selecionados; 45 do STJ, ou 25\%; 117 do TRF $1^{\text {a }}$ Região, ou 65\%; 05 do TRF $2^{\text {a }}$ Região, ou 3\%; 07 do TRF $3^{\text {a }}$ Região, ou 4\%; 01 do TRF da $4^{\text {a }}$ Região, e; 01 do TRF da $5^{\text {a }}$ Região, totalizando a soma de ambos aproximadamente $1 \%$.

31 A separação dos acórdãos em temas e sub temas, foi a forma eleita para realizar o agrupamento de assuntos similares.

32 Para a classificação dos acórdãos dentro deste critério, o pesquisador responsável ao analisar a redação do voto e da ementa, ideitificava se a argumentação representava a aplicação do princípio da prevenção e/ou se existia uma questão de incerteza científica a justificar a aplicação do princípio da precaução. Foram classificados como de aplicação incorreta do princípio da precaução, os acórãos que meramente o citaram na redação do voto ou em ementas transcritas neste, bem como os que mesmo citando-o, não o levaram em consideração para a conclusão do voto. Foram identificados, também, os critérios eventualmente utilizados pelo relator para a invocação da aplicação do princípio (de forma correta ou não).

33104 acórdãos foram assim classificados.

3443 acórdãos.

Veredas do Direito, Belo Horizonte, $\cdot$ v.15 $\cdot$ n.32 $\cdot$ p.327-356 $\cdot$ Maio/Agosto de 2018 
processuais que não são sólidas, pois, são julgados que estão amparados, tão somente, na identificação concomitante dos elementos cautelares e não em uma análise mais profunda e detalhada.

Percebe-se, então, que os órgãos administrativos devem levar em consideração o princípio da precaução na aplicação de medidas para atenuar as infrações administrativas e as sanções penais, como é previsto, por exemplo, no artigo 54, parágrafo terceiro da Lei 9.605/1998, sobre infrações administrativas e crimes ambientais. Os riscos certos e incertos são, por esses meios, avaliados, resultando por vezes na adoção de medidas provisórias de avaliação dos riscos. Na esfera reparatória, um dos efeitos mais relevantes constatado nas decisões é a possibilidade de inversão do ônus da prova em razão a aplicação direta do princípio. Eis que o princípio gera efeitos tanto por meio de medidas que devem ser adotadas no contexto das autorizações administrativas de atividades potencialmente poluidoras (1), como na possibilidade de inversão do ônus da prova para a reparação de danos(2).

\subsection{A influência do princípio nas autorizações administrativas das atividades potencialmente poluidoras}

O princípio da precaução pode ser interpretado no contexto das autorizações administrativas das atividades potencialmente poluidoras questionadas diante do Poder Judiciário. A maneira pela qual o princípio é interpretado pode ser constatada nas questões relacionadas à exigência de informação prévia no caso de potencialidade de realização de danos ambientais com efeito, por exemplo, na exigência de estudo de impacto ambiental e na anulação de autorizações administrativas outorgadas sem a exigência de condicionantes necessárias para a devida prevenção de um dano. Antes de analisar o impacto do princípio nas medidas administrativas é relevante indicar a relação entre o âmbito administrativo e o judiciário na aplicação do princípio da precaução.

Um primeiro exemplo da implementação do princípio para a hipótese da prevenção de danos pode ser constatadonas situações que exigem - como obrigação de fazer - a realização de estudos de impacto ambiental. O exemplo mais característico é um julgado relacionado ao tema dos organismos geneticamente modificados (OGMs) ${ }^{35}$. Uma ação 35 TRF $1^{a}$ Região, 2000.01.00.014661-1/DF, decisão de 8 de agosto de 2000. No sentido contrário: STJ, Resp n ${ }^{\circ} 592.682 /$ RS, decisão de 6 de dezembro de 2005. 
cautelar foi ajuizada pelo Instituto de Defesa do Consumidor perante a Justiça Federal da $1^{\text {a }}$ Região. O magistrado de primeira instância decidiu, ao interpretar a aplicação do princípio da precaução, que o estudo deveria ser realizado para demonstrar os possíveis impactos da atividade na saúde e no meio ambiente, mesmo que não exista certeza científica sobre o tema. Por outro lado, em segunda instância, o TRF da $1^{\text {a }}$ Região não aplicou o princípio, pois a Turma julgadora entendeu que tanto estudos quanto normas específicas já tinham sido realizados sobre o tema da segurança alimentar, do comércio e da etiquetagem ${ }^{36}$. Esse caso gerou um efeito interessante na produção normativa mais específica sobre o tema, o que ocorreu após a decisão da primeira instância.

Em uma outra situação, foi impetrado um mandado de segurança ${ }^{37}$ contra o ato que não liberou a plantação e o comércio de um cultivares da soja. O órgão administrativo competente não tinha autorizado as atividades mencionadas, porque não detinha informações precisas sobre as possíveis consequências para a saúde e para o meio ambiente do produto sob análise. $\mathrm{O}$ acórdão do tribunal confirmou a decisão administrativa no sentido de que os estudos sobre a cor do hilo da soja ainda não eram conclusivos quanto aos seus efeitos e que, portanto, seria denegada a segurança. Nos termos do acórdão, "De tudo que consta nos autos, não se verifica a alegada omissão da autoridade apontada como coatora a justificar a concessão da ordem. Isso porque a questão relativa à análise de sementes e cultivares requer estudos, pesquisas e testes laboratoriais a fim de que seja criada norma regulamentadora sobre a liberação do plantio e comercialização de sementes de soja pelos órgãos responsáveis da administração pública".

Interessante ressaltar que, em casos nos quais o conhecimento científico foi considerado pelo tribunal como mais detalhado, como na hipótese do milho modificado, não houve aplicação do princípio da precaução e a atividade pôde ser realizada ${ }^{38}$.

A anulação de autorizações administrativas outorgadas por instituições sem o devido cumprimento de todos os procedimentos previstos em lei é também um exemplo dos efeitos da implementação do princípio da precaução. Um caso emblemático sobre o tema foi de experimentos com plantas bioinseticidas apresentado pelo Ministério Público Federal por meio de uma ação civil pública contra a União. Foram apontadas ilegalidades na

36 Por exemplo, Decreto n ${ }^{\circ} 8.971 / 2001$ e Decreto ${ }^{\circ}$ 4680/2003.

37 STJ, MS n. 16.074/DF, decisão de31 de agosto de 2012.

38 TRF 4 $4^{a}$ Região, Apelação civel n. 502088411.2013.404.7000/PR, decisão de 17 de julho de 2015. 
cultura de OGMs que funcionavam como agentes biológicos de controle de pragas. Para essa situação não foi exigido o registro da atividade (Registro Especial Temporário - RET) das empresas de biotecnologia ${ }^{39}$ pela organização competente. Como as plantas geravam riscos incertos para uma grande variedade de insetos, que não eram necessariamente nocivos às plantas, o princípio da precaução foi invocado para demandar mais estudos no sentido de conhecer mais profundamente os efeitos da planta no meio ambiente e na saúde. Os julgadores, tanto de primeira quanto de segunda instância,decidiram a favor da adoção de medidas cautelares e suspenderam as autorizações.

O princípio também foi interpretado no mesmo sentido, ou seja, acerca da necessidade de realização de estudos, no contexto dos julgados que decidiram sobre a construção de barragens ${ }^{40}$. Um acórdão assinalou que mesmo quando não há normas sobre a exigência de estudos de impacto, a apresentação deste seria mandamental a fim de se aplicar o princípio da precaução ${ }^{41}$.

Podem ser citados, no mesmo sentido, os litígios relativos à emissão de ondas eletromagnéticas e a instalação de antenas para as conexões de telefones celulares. Há decisões de primeira e de segunda instância fundadas no princípio da precaução. Medidas como a interrupção da construção de linhas de transmissão em razão dos riscos para a saúde e para o meio ambiente foram adotadas, assim como decisões que permitiram as construções ${ }^{42}$. Todas essas ações foram reunidas em um único processo no Supremo Tribunal Federal para uma decisão única ${ }^{43}$, que foi tomada em 2016. A questão principal era de determinar o montante de ondas eletromagnéticas diante do qual a população poderia ser submetida e se essa quantia poderia ser superior ao parâmetro estabelecido pela Agência Nacional de Energia Elétrica-ANEEL ${ }^{44}$. Em 2015 o STJ, ao analisar o RE $N^{\circ} 627189 / \mathrm{SP}$, confirmou a decisão da segunda instância no sentido de que em alguns casos poderiam ser feitos estudos e adotados padrões

39 TRF $1^{\text {a }}$ Região, Apelação civel n. 2001.34.00.010329-1/DF, decisão de 12 de fevereiro de 2004. 40 TRF $1^{a}$ Região, Apelação cível n. 0005591-31.2007.4.01.0000/RR, decisão de 27 de abril de 2009; TRF $1^{\text {a }}$ Região, Apelação cível n. 0002955-06.2001.4.01.4300/TO, decisão de 12 de julho de 2007; TRF $1^{\text {a }}$ Região, Embargos de declaração na Apelação civel n. 0000709-88.2006.4.01.3903/PA, decisão de 27 de agosto de 2012;

41 STJ, Resp n.1.172.553/PR, decisão de 27 de maio de 2014.

42 STJ, AgRg na Medida cautelar no 17.449/RJ, decisão de 22 de setembro de 2011.

43 STF, Repercussão geral no Rec. Extraord. n. 627.189/SP, decisão de 22 de setembro de 2011; STJ, AgRg na Medida Cautelar n. 17.449/RJ, decisão de 22 de setembro de 2011.

44 Segundo Lei n. 11.934/2009 e, principalmente, Resolução Normativa n. 398/2010. 
superiores ao estabelecido pela ANEEL ${ }^{45}$. Contudo, em julho de 2016, o STF reformou diversas decisões favoráveis à suspensão de atividades conectadas à emissão de ondas eletromagnéticas no sentido de que os limites adotados pela ANEEL eram suficientes e, portanto, não seriam necessários outros estudos específicos sobre os padrões a serem adotados sobre o tema. Observa-se, por meio desse caso, o impacto do princípio na interpretação das medidas administrativas aplicáveis, pois houve constante questionamento das autorizações administrativas outorgadas e suspensas para a construção de linhas de transmissões, o que resulta em evidente falta de segurança jurídica para a atividade ${ }^{46}$.

Esse raciocínio pode também ser visto no caso da exploração de recursos localizados na plataforma continental ${ }^{47}$. Em uma ação civil pública ajuizada pelo Ministério Público Federal em desfavor da empresa Chevron do Brasil e da Transocean Brasil, a decisão judicial foi a favor da interrupção da atividade de exploração de petróleo até que: a) as empresas estabelecessem procedimentos ligados à implementação de um Plano de abandono do poço, prevendo uma multa de quinhentos milhões de reais em caso de falha no cumprimento da decisão; b) que estudos mais aprofundados sobre o tema fossem feitos. Estudos complementares já foram exigidos, igualmente, em casos relacionados à construção de barragens ${ }^{48}$.

No sentido contrário - no qual não há anulação ou suspensão de autorizações administrativas concedidas - há uma decisão do Superior Tribunal de Justiça ${ }^{49}$ que afirmou que não era razoável e proporcional interromper a atividade de construção de uma barragem. Neste caso, que concerne à construção de uma Barragem sobre o rio Tibagi/PR (UHE Mauá, Município de Telêmaco Borba), o Tribunal a quo havia suspendido a autorização em razão de riscos incertos que a atividade poderia causar ao meio ambiente. A decisão do STJ sobre essa suspenção fez prevalecer o entendimento de que a atividade não poderia ser suspensa, pois autorizações tinham sido concedidas com base em exigências específicas que estavam sendo cumpridas pela empresa. Segundo o entendimento do tribunal, a suspensão da construção teria, de uma parte, efeitos na ordem econômica, administrativa e social e, de outra parte, a proteção do meio ambiente já teria

45 STJ, Recurso Especial no 1.437.979/CE, decisão em 10 de novembro de 2015.

46 Sobre o tema dos campos eletromagnéticos ver os julgados específicos sobre o tema.

47 TRF 2 $2^{\text {a }}$ Região, Agravo de instrumenton. 0004075-70.2012.4.02.0000, decisão de 31 de julho de 2012.

48 STJ, 1863/PR, decisão de 18 de fevereiro de 2009.

49 STJ, 1863/PR, decisão de 18 de fevereiro de 2009. 
sido objeto de controle. No mesmo sentido foi a decisão do STF no caso dos campos eletromagnéticos no qual o princípio da proporcionalidade foi utilizado para justificar a decisão no sentido de que a construção de linhas de transmissão não deveria ocorrer caso os standards estabelecidos pela ANEEL tivessem sido cumpridos.

Em suma, observa-se que anulações ou suspensões de autorizações administrativas já ocorreram com base na interpretação do princípio da precaução. Todavia, não há clareza quanto aos critérios utilizados na tomada dessas decisões, o que será debatido em momento posterior nesse artigo. Além desse efeito, a possibilidade de inversão do ônus da prova também pode ser citada como um impacto da interpretação do princípio.

\subsection{A influência do princípio na inversão do ônus da prova}

No contexto do direito da responsabilidade civil, o princípio da precaução influenciou a flexibilidade do nexo de causalidade ${ }^{50}$, por exemplo, pela inversão do ônus da prova do dano ${ }^{51}$ (MACHADO, 2015, p. 117-118; MILARÉ, 2001, p. 1499-1515). Os casos sobre a construção de barragem ${ }^{52}$ e sobre a exploração de petróle $0^{53}$ podem ser mencionados como exemplos. Os limites dessa constatação estão relacionados, uma vez mais, à falta de critérios que possam garantir esse efeito da interpretação do princípio da precaução. É importante apresentar as condições normativas relacionadas à inversão do ônus da prova no Brasil antes de demonstrar o efeito do princípio da precaução nos casos ambientais.

Os argumentos principais que justificam a inversão do ônus da prova estão previstos na Lei da Ação Civil Pública, artigo 21 (Lei 7.347/1985) e no Código do Consumidor, artigo $6^{\circ}$, VIII ${ }^{54}$. Tratam-se de exceções à regra geral constante do Código de Processo Civil, artigo 373 , I que dispõe caber ao autor o ônus da prova sobre o seu direito. Os critérios segundo os quais a inversão é possível, no caso do processo civil são: a previsão normativa sobre essa possibilidade e a condição de

50 STJ, Resp n. 769.753/SC, decisão de 9 de setembro de 2009.

51 STJ, Resp n. 1330027/ SP, 3a. turma, decisão de 11 de junho de 2012; TRF 2, Agravo de instrumento n.0004075-70.2012.4.02.0000, $5^{\text {a }}$. turma, decisão de 31 de julho de 2012.

52 STJ, Resp 1330027 / SP, $3^{a}$. turma, decisão de 11 de junho de 2012.

53 STJ, Resp 883656/RS, decisão de 9 de março de 2010.

54 Há autores que entendem não existir um dispositivo que permita a inversão do ônus da prova em matéria de direito ambiental. O dispositivo existiria somente em direito do consumidor. Sobre o assunto veja: (MILARÉ, 2001, p. 1499). 
vulnerabilidade do demandante (hipossuficiência). Após a edição da Lei n. 13.105/2015, ou do Novo Código de Processo Civil, a inversão do ônus da prova também passou a ser possível diante das peculiaridades da causa, relacionadas à impossibilidade ou à excessiva dificuldade de cumprir o encargo. Desta forma, o magistrado passou a ter o poder de distribuir, de forma dinâmica, o ônus da prova, desde que o faça por meio de decisão fundamentada. Esses critérios são cumpridos em alguns casos, como, por exemplo, no confronto entre pescadores e empresas responsáveis pela construção de barragens. Com relação ao segundo critério, há uma interpretação que começa a ser majoritária, mais que deve ser objeto de análise mais precisa por parte dos juízes.

Em um caso sobre a construção de uma barragem ${ }^{55}$, o segundo critério foi interpretado como cumprido no contexto de efeitos tanto à fauna aquática do rio Paraná quanto às atividades dos pescadores da região. Os pescadores postularam a obtenção de indenização em razão dos prejuízos econômicos sofridos, ligados à construção da barragem. Na decisão de primeira e de segunda instância, o processo foi extino em razão da falta de provas científicas sobre o nexo de causalidade entre a construção da barragem e os impactos sobre a fauna aquática. Todavia, o STJ,amparado em seus próprios precedentes ${ }^{56}$, aceitou ser possível o processamento da demanda para que se apurasse a responsabilidade da empresa, cabendo a ela demonstrar que a construção da barragem não geraria impactos na fauna aquática e, consequentemente, na pesca. O STJ permitiu a inversão do ônus da prova para que a empresa comprovasse se houve ou não dano. O princípio da precaução foi uma das fontes utilizadas para justificar a inversão do ônus da prova de maneira complementar aos argumentos ligados ao processo (previsão normativa da possibilidade e condição de hipossuficiência do demandante). Sem analisar aqui se se trata da aplicação do princípio da prevenção ou da precaução, é possível constatar que o princípio impactou na análise do tema e gerando efeitos nos critérios clássicos processuais.

Todavia, houve outras decisões que interpretaram o elemento da hipossuficiência de uma maneira diferente daquela do direito processual clássico. Em um acórdão do STJ ${ }^{57}$, a aplicação do princípio da precaução gerou um efeito de inversão do ônus da prova em um processo no qual o demandante era o Ministério Público e o demandado uma empresa privada.

55 STJ Resp n ${ }^{\circ} 1.330 .027 / \mathrm{SP}$, decisão de 11 de junho de 2012. 56 STJ, Resp $n^{\circ}$ 1.049.822/RS, decisão de 23 de abril de 2009. 57 STJ, Resp no 972.902/RS, decisão de 25 de agosto de 2009. 
O demandado argumentou no sentido de que o Ministério Público não cumpria com a condição de hipossuficiência para que a inversão do ônus da prova fosse aplicada. O STJ afirmou que poderia ocorrer a inversão do ônus da prova, pois a empresa, ao realizar atividades potencialmente perigosa, deve demonstrar que os seus serviços são seguros e "que o caráter público e coletivo do bem objeto da proteção jurídica justifica a inversão do ônus da prova". Considerando o Ministério Público como o representante da sociedade, a inversão do ônus da prova se fundamentou em favor da sociedade e do bem objeto da proteção. O princípio da precaução foi interpretado de maneira conjunta com outros princípios, como o princípio "in dubio pro natura"e o princípio da boa-fé (BRYNER, 2015, p. 245-258), no sentido de que é da empresa o ônus de demonstrar que a sua atividade integra a proteção ambiental.

É possível interpretar, em função dos casos acima, que, no contexto dos danos ambientais, a inversão do ônus da prova é justificada por argumentos substanciais e processuais. A constatação pelo juiz, da existência de um bem ou objeto de natureza coletiva, como o meio ambiente, o autoriza a decidir em favor da inversão do ônus da prova. A parte hipossuficiente, nesse contexto, é a sociedade, representada pelo Ministério Público.

Diante doque foianalisado, observa-seaberturaparaainterpretação do princípio no sentido da garantia da prevenção e da reparação de danos ambientais. Contudo, ainda subsiste insegurança jurídica decorrente da imprecisão conceitual e da falta de critérios objetivos para a utilização do princípio em demandas ambientais.

\section{A implementação inapropriada do princípio em razão de bases conceituais imprecisas}

O princípio da precaução não é, muitas vezes, precisamente conceituado e aplicado na jurisprudência brasileira ${ }^{58}$. A utilização do princípio foi percebida como um "coringa"que é lançado diante de situações complexas que exigiriam uma maior cautela na análise jurídica dos fatos e dos fundamentos, por parte dos juízes. Uma forma de garantir segurança jurídica na utilização do princípio, como fundamento legal de decisões judiciais, seria o estabelecimento de critérios objetivos que, uma

58 Conforme dito anteriormente, $57 \%$ dos acórdãos analisados não aplicaram o princípio da precaução amparando-se em critérios técnicos, ou diante da existência de incerteza científica. 
vez identificados, justificariam a sua aplicação.

A inexistência de critérios, na maioria dos textos judiciais analisados na pesquisa, amplia a insegurança jurídica para atividades que exploram recursos naturais. $\mathrm{O}$ direito internacional é um parâmetro interessante no que concerne à cautela e ao cuidado que as jurisdições internacionais possuem ao interpretar o princípio que, na esfera nacional, ainda carece de uma base conceitual sólida.

O princípio da precaução se desenvolve seguindo o caminho típico das normas ambientais: primeiramente, o princípio consagrou-se em declarações políticas não vinculantes; em um segundo momento, o princípio começou a fazer parte de preâmbulos de tratados ${ }^{59}$; e, finalmente, a norma foi fixada em dispositivos operacionais ${ }^{60}$ (DAILLIER et al., 2009, p. 1453; HAUTEREAU-BOUTONNET et al., 2015; KISS; BEURIER, 2010, p. 156-158; MALJEAN-DUBOIS, 2008, p. 75-82; PRIEUR, 2014, p. 58-72; SANDS et al., 2012, p. 217-228) de tratados ambientais específicos(ELLIS, 2006, p. 445).Apesar desse desenvolvimento e da adoção do princípio da precaução em várias ordens jurídicas nacionais, regionais e internacionais, a sua utilização é ainda controversa ${ }^{61}$ (BIRNIE; BOYLE; REDGWELL, 2009, p. 155). O principal argumento para recusar uma normatividade independente ao princípio da precaução é o de sua definição vaga, tendo em vista a multiplicação de interpretações e de finalidades a ele conectadas ${ }^{62}$.

A situação da interpretação do princípio no Brasil não é diferente. Todavia, contrariamente ao que se passa no direito internacional ambiental, não há dúvidas sobre a existência de obrigações ligadas ao princípio da precaução. Em razão da previsão implícita no texto da Constituição Federal, especificamente no artigo 225, parágrafo primeiro, V, e também da

59 Preâmbulo da Convenção sobre a Diversidade Biológica (CDB), por exemplo.

60 O princípio foi formalizado na origem pela Declaração de Bergen de 1990. Após essa primeira aparição o princípio foi formulado em sucessivas convenções, por exemplo, a Convenção de Bamako de 1991 sobre a proibição de importação de dejetos perigosos na África (artigo $4^{\circ}, \S 3^{\circ}$ ) ; a Declaração do Rio de 1992 (princípio 15) ; a Convenção Quadro de 1992 de Mudanças Climáticas (artigo $3^{\circ}, \S 3^{\circ}$ ) ; a Convenção de Diversidade Biológica (preâmbulo); a Convenão de Sofia de 1994 sobre a proteção do Danúbio (art. $2^{\circ} . \S 4^{\circ}$ ).

61 A título de exemplo sobre a hesitação da jurisprudência acerca do princípio da precaução, ver CIJ, decisão de 25 de setembro de 1997,Projeto Gabickovo-Nagymaros, Rec., p. 68, §114, e também ORD, grupo especial, relatório de 29 septembre 2006, CE-Approbation et commercialisation des produits biotechnologiques, $\S 7.88-7.89$.

62 A pluralidade dos objetivos do princípio da precaução é evidente a partir da análise da variedade de matéria das convenções que o consagram : o princípio da precaução pode ser geral, como o caso da Declaração de Bergen ou do Rio, ou específico, como nos casos da Convenção de Bamako (dejetos perigosos), da UNFCCC (mudanças climáticas), da convenção de Sofia (proteção do Danúbio), Protocolo de Cartagena (OGMs). 
previsão expressa em vários dispositivos nacionais ${ }^{63}$, os juízes brasileiros utilizam o princípio da precaução como uma regra de direito, muitas fezes como a principal fonte de argumentação - uma espécie de argumento de autoridade ${ }^{64}$ - frente a uma larga quantidade de problemas jurídicos ambientais, de modo pouco preciso, em detrimento da segurança jurídica. Dessa maneira, o princípio é por vezes entendido como uma norma que deve ser aplicada desvinculada de critérios e da legalidade normalmente exigida para a aplicação de um princípio.

Assim, é importante analisar a ausência de um regime jurídico definido para o princípio (1), assim como a inexistência, no sistema jurídico brasileiro, de critérios objetivos que fundamentem a aplicação do princípio(2).

\subsection{O regime jurídico indefinido do princípio no Brasil}

O princípio da precaução não possui um regime jurídico definido no Brasil (MILARÉ, 2001). Essa constatação pode ser feita, principalmente, a partir do desconhecimento dos juízes, acerca da lógica que contribuiu para a concretização do princípio no direito internacional ambiental, desconhecimento que conduziu a uma confusão entre o princípio da precaução na condição de princípio e na condição de regra jurídica. Existe, ainda, uma confusão entre o conteúdo do princípio da precaução com o conteúdo do princípio da prevenção ${ }^{65}$. Ademais, há ocasiões nas quais o princípio é aplicado como razão de decidir, sem uma devida análise quanto à conformidade da sua aplicação ${ }^{66}$. Trata-se de circunstâncias que resultam na banalização do princípio $^{67}$, ou seja, no distanciamento, na prática, da 63 Art. $1^{\circ}$ e Art. $5^{\circ}$, X, Decreto federal brasileiro ${ }^{\circ} 5.300$ de 7 de dezembro de 2004, que regulamenta a Lei ${ }^{\circ}$ 7.661, de 16 de maio de 1988, que institui o Plano Nacional de Gestão Costeira ; Art. $1^{\circ}$ da Lei federal $\mathrm{n}^{\circ} 11.105$ de 24 de março de 2005 , que estabelece as normas de segurança e de controle das atividades ligadas aos OGM ; art. $3^{\circ}$ da Lei federal no 12.187 de 29 de dezembro de 2009, que cria a Política nacional de mudanças climáticas e artigo $6^{\circ}$, I, da Lei federal n 12.305 , de 2 de agosto de 2010, a Política nacional de resíduos sólidos.

64 Em 89 acórdãos (de um total de 182 analisados), não obstante a existência de referência ao princípio da precaução (no voto ou em sua ementa), este não foi analisado ou foi meramente citado na redação deste, sem que tenha influído diretamente na sua conclusão, ou seja, não houve subsunção dos fatos as bases jurídicas do princípio. Esta quantidade de julgados representa aproximadamente $49 \%$ de todos os acórdãos pesquisados.

65 Há autores que confirmam que o princípio da precaução deve ser analisado da mesma forma que o princípio da prevenção.

66 Por exemplo, TRF $1^{\text {a }}$ Região,Agravo de Instrumento em Ação Civil Pública, n. 003122388.2009.4.01.0000/BA, decisão de 08 de fevereiro de 2013, e Remessa exofficio em Mandado de Segurança n. 0043161-04.2010.4.01.3700/MA, decisão de 06 de março de 2013.

67 Vide, por exemplo, os seguintes julgados: TRF $1^{\text {a }}$ Região, Apelação Civil, n. 000049617.2008.4.01.3902/PA, decisão de 30 de setembro de 2015; TRF $1^{\mathrm{a}}$ Região, Apelação Civil, n. 
razão de ser do princípio.

O princípio da precaução possui, conceitualmente, uma característica geral de prevenir um impacto ambiental, mas esse princípio se distingue da prevenção em razão do risco que ele deve regular. A aplicação do princípio da prevenção é feita quando os perigos resultantes de uma atividade econômica são conhecidos, mesmo se uma incerteza mínima sobre a ocorrência, ou a gravidade, ou a dimensão do dano exista (MACHADO, 2015, p. 99; PRIEUR, 2014, p. 60; SANDS et al., 2012, p. 218). Há uma certeza que a exposição ao perigo conduzirá ao dano e ao direito à reparação. Por sua vez, o princípio da precaução deve ser utilizado quando há um risco segundo o qual se desconhece quais são as exatas repercussões da atividade no meio ambiente ou na saúde. O princípio possui a função de limitar o risco, de regulá-lo, já que o risco zero é impossível de evitar (NOIVILLE, 2006, p. 37). A incerteza científica sobre as consequências de cada atividade é o elemento central para diferenciar os dois princípios(DAILLIER et al., 2009, p. 1453). Para que o princípio da precaução seja utilizado, as consequências do risco devem ser amparadas em critérios tais como a magnitude ou gravidade do risco $^{68}$ e a irreversibilidade ${ }^{69}$ (BIRNIE; BOYLE; REDGWELL, 2009, p. 153; HAUTEREAU-BOUTONNET et al., 2015, p. 110), o que exige uma complexa e detalhada análise na subsunção do princípio e do caso concreto por parte do operador.Essa complexidade ainda não faz parte das constatações exteriorizadas pelos julgamentos dos tribunais nacionais que por vezes simplificam e banalizam a aplicação do princípio $^{70}$. O leading case na delimitação de critérios é o Recurso extraordinário ${ }^{71} 627189$, decidido em 2016, com relação aos possíveis impactos dos campos eletromagnéticos na saúde e no meio ambiente. Os critérios elaborados

0003450-21.2008.4.01.4101/RO, decisão de 18 de fevereiro de 2016; TRF $1^{a}$ Região, Apelação Civil, n. 0004398-60.2008.4.01.4101/RO, decisão de 02 de dezembro de 2016; TRF $1^{\text {a }}$ Região, Apelação Civil, n. 0005186-84.2011.4.01.3902/PA, decisão de 28 de janeiro de 2016;

68 STJ, Agravo regimental na Suspensão de liminar e de sentença n $^{\circ}$ 1.419/DF, decisão de 08 de janeiro de 2013; STJ, Agravo regimental na suspensão de segurança n. 2.333/CE, decisão de 29 de junho de 2010; TRF $1^{\text {a }}$ Região, Apelação cível n. 0000066-05.2007.4.01.3804/MG, decisão de 03 de setembro de 2016; TRF $1^{\text {a }}$ Região, Apelação civel n. 0000162-61.2000.4.01.3902/PA, decisão de 23 de abril de 2007; TRF 1 ${ }^{a}$ Região, Apelação civel n. 0002955-06.2001.4.01.4300/TO, decisão de 14 de novembro de 2007; TRF $1^{\mathrm{a}}$ Região, Apelação civel n. 0005456-86.2003.4.01.4000/PI, decisão de 03 de maio de 2008, entre outros.

69 Artigo 54, parágrafo 3, da Lei no 9.605/1998, a Lei de crimes ambientais.

70 TRF $1^{\text {a }}$ Região,Agravo de Instrumento n. 0018353-06.2012.4.01.0000/MA, decisão de 31 de julho de 2013 e TRF $1^{\text {a }}$ Região, Apelação Cível n. 0036559-29.2006.4.01.9199/PI, decisão de 10 de setembro de 2013.

71 STF, RE 627189, decisão de 08 de junho de 2016. 
nesse caso concreto serão objeto de análise mais detalhada na segunda parte desse artigo $^{72}$.

Alguns juízes brasileiros, mesmo nos tribunais superiores, aplicam o princípio de precaução a situações que exigem a utilização do princípio da prevenção. Há exemplos dessa confusão, mesmo no quadro do $\mathrm{STF}^{73}$ e do $\mathrm{STJ}^{74}$, ambos encarregados da harmonização das normas constitucionais e infraconstitucionais, respectivamente. Foi realizado um estudo ${ }^{75}$ que examinou os acórdãos proferidos pelo TRF da 1a Região, entre os anos 2013 e 2014,nos quais houve a aplicação do princípio. Constatou-se que, de um total de 57 (cinquenta e sete) acórdãos onde o princípio da precaução foi mencionado, 57\% (cinquenta e sete por cento) destes não utilizaram quaisquer critérios que justificasse a sua invocação, somente 23 julgados fizeram uma análise da possibilidade de utilizar o princípio segundo critérios $^{76}$ específicos conectados à gravidade ou à irreversibilidade do dano ${ }^{77}$.

Do total de acórdãos identificados no referido estudo, 23 deles, ou $43 \%$, foram proferidos em sede de processos cautelares/liminares/ agravos, ou seja, em processos nos quais houve um exame superficial da controvérsia. Tal constatação, considerando-se a construção de uma jurisprudência sem bases conceituais sólidas e formulada em situações nas quais não houve qualquer análise meritória, é elemento que deve ser objeto de estudos mais aprofundados por parte da comunidade acadêmica.

Nesta pesquisa, podem ser referidas situações que invocaram o princípio como razão de decidir, porém sem a demonstração da existência de uma incerteza científica, aplicando-o como se preservação fosse, tais como

72 Além disso, ver o artigo específico sobre campos eletromagnéticos desse livro.

73 STF, Agravo regimental no Agravo de instrumento n. 781.547/RS, decisão de 13 de março de 2012;

74 STJ, Embargos de declaração no Resp n. 843.978/SP, decisão de 03 de julho de 2013.

75 F. R. FERREIRA. Pesquisa feita por Fabrício Ramos Ferreira no Grupo de Pesquisa Direito dos Recursos Naturais e Sustentabilidade (GERN) da Faculdade de Direito da Universidade de Brasília.

$7630 \%$ invocaram o a previsibilidade do dano; $9 \%$ afastaram a aplicação do princípio da precaução; $2 \%$ se referiram à magnitude $\mathrm{e}$ às consequências nocivas do dano; $2 \%$ se referiram à tolerabilidade do meio quanto aos impactos previstos;

77 Por exemplo, TRF 1 ${ }^{a}$ região, Apelação Cível n. 0002591-78.2007.4.01.3700/MA, decisão de 19 de novembro de 2014; TRF 1ª região, Apelação em Mandado de Segurança n. 0012724-

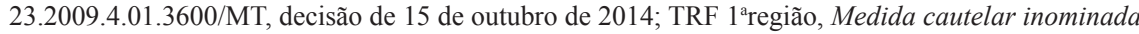
n. 0070024-73.2009.4.01.0000 (1) /MT, decisão de 15 de outubro de 2014. 
ao funcionamento de usinas hidroelétricas ${ }^{78}$ ou infrações administrativas ${ }^{79}$, bem como hipóteses em que o princípio foi expressamente afastado ${ }^{80}$, cabendo ressaltar que, na fundamentação do voto, houve a utilização de critérios claros e da ponderação de valores e princípios.

Com relação ao STJ, pode ser mencionado o exemplo do julgamento do caso $1279 / \mathrm{PR}^{81}$. A situação apreciada dizia respeito à instalação de um aterroem uma área de proteção ambiental próxima à um aquífero. Neste caso, os perigos que podem ser cometidos por empresas atuantes nessa atividade são conhecidos, fato que conduz à necessidade de adotar medidas a partir da aplicação da prevenção. $O$ fato de não se conhecer a exata dimensão do possível dano que será causado pela atividade não justifica a referência ao princípio da precaução, fundamento utilizado pelo STJ para proibir a conclusão da construção em questão. Em outras decisões, por exemplo, a queima da palha da cana de açúcar ${ }^{82}$, atividade enquadrada pelo direito brasileiro por seus efeitos nocivos ao meio ambiente - foi objeto de regulação judicial pelo princípio da precaução.

A situação no STF é também grave em razão da importância das decisões tomadas por essa Corte. Já houve casos nos quaiso Tribunal confirmou uma decisão tomada por um tribunal de segunda instância aplicando o princípio da precaução em um caso de confronto entre vizinhos sobre a conformidade do nível de barulho produzido pelo ar condicionado, segundo a legislação nacional ${ }^{83}$.A ausência de manifestação do congresso nacional, quanto ao fato de obras atingirem terras indígenas, também foi objeto de invocação do princípio, ainda que em voto invocado pela

78 TRF $1^{a}$ Região, Apelação civel n. 0000968-19.2011.4.01.3900/PA, decisão de 14 de janeiro de 2014; TRF 1 ${ }^{a}$ Região Agravo regimental na apelação cível n. 0000968-19.2011.4.01.3900/PA, decisão de 14 de janeiro de 2014; TRF $1{ }^{\text {a }}$ Região, Apelação civel n. 0025999-75.2010.4.01.3900/PA, decisão de 22 de abril de 2014 .

79 TRF $1^{\text {a }}$ Região, Apelação civel n. 0000914-26.2006.4.01.3901/PA, decisão de 21 de fevereiro de 2014; TRF 1ª Região, Apelação civel n. 0043161-04.2010.4.01.3700/MA, decisão de 13 de março de 2013;

80 TRF $1^{a}$ Região, Apelação cível n. 0000165-29.2008.4.01.4001/PI, decisão de 01 de março de 2013; TRF 1'Região, Apelação cível n. 0001317-69.2009.4.01.4101/RO, decisão de 13 de fevereiro de 2013; TRF $1^{a}$ Região, Apelação cível n. 0001659-80.2009.4.01.4101/RO, decisão de 13 de fevereiro de 2013; TRF $1{ }^{a}$ Região, Apelação civel n. 0003468-42.2008.4.01.4101/RO, decisão de 01 de março de 2013; TRF $1^{a}$ Região, Agravo de instrumento n. 0073503-06.2011.4.01.0000/RO, decisão de 11 de março de 2013;

81 STJ, AgRg na Suspensão de Liminar e sentença, 1279/PR, decisão de 16 de março de 2011.

82 STJ, Recurso Especial n. 965.078/SP, decisão de 20 de agosto de 2009.

83 STF, Agravo Regimental,n. 781.547/ RS, decisão de 09 de fevereiro de 2012. 
divergência, que ficou vencida ${ }^{84}$.Em um outro caso ${ }^{85}$, um dos ministros afirmou que seria necessário utilizar o princípio da precaução para justificar a competência da Justiça Federal brasileira para julgar casos de comércio ilegal de animais silvestres. Conforme expôs o relator: "segundo esse princípio de Direito internacional do meio ambiente [precaução], os povos devem estabelecer mecanismos para combater preventivamente as ações que ameaçam a utilização sustentável dos ecossistemas" ${ }^{\prime 6}$.

Apesar das críticas apresentadas acima, reconhece-se que os tribunais contribuíram para a implementação do princípio da precaução no Brasil. Por exemplo, no caso da introdução dos OGMs no país, os tribunais tiveram um papel central na proibição da plantação e do comércio dos OGMssem a realização de estudos mais detalhados sobre os efeitos ambientais(MACHADO, 2015, p. 110-121), especificamente utilizando o estudo de impacto ambiental como ferramenta para justificar as autorizações administrativas ${ }^{87}$.

A confusão em torno do princípio da precaução no Brasil, demonstrada nos parágrafos anteriores, é também o resultado da ausência de critérios objetivos para aplica-lo. Esses critérios poderiam ser estabelecidos por leis ou pela jurisprudência, que iniciou esse processo em alguns julgamentos.

\subsection{A inexistência de critérios objetivos para a previsibilidade da utilização do princípio}

Não há, no Brasil, normas que estabeleçam critérios objetivos para garantir segurança jurídica à implementação do princípio da precaução ${ }^{88}$. Nesse contexto, parece que a falta de critérios objetivos é um dos fatores que contribuem para uma utilização banalizada ${ }^{89}$, sem conteúdo preciso

84 STF, Agravo Regimental na Medida cautelar na ação cível originária,n. 876/BA, decisão de 01de agosto de 2008 .

85 STF, Recurso Extraordinário n.737.977/SP, decisão de 04 de setembro de 2014.

86 STF, Recurso Extraordinário n.737.977/SP, decisão de 04 de setembro de 2014, pág. 07.

87 Ainda sobre OGMs, o poder judiciário brasileiro terá a ocasião de julgar uma ação direta de inconstitucionalidade que demanda a anulação da lei que rege a matéria no Brasil, a ADI 3526. Um dos argumentos propostos pelo Parquet federal para invalidar alguns dispositivos da lei 11.105 é a observância do princípio da precaução.

88 A União Européia, por exemplo, publicou uma lista detalhada indicando os critérios que devem ser seguidos pelas autoridades comunitárias no momento de aplicar ou não o princípio da precaução. A lista é disponível em: $<$ http://eur-lex.europa.eu/legal-content/FR/TXT/?uri=URISERV:132042>. Acesso em julho de 2017.

$8957 \%$ dos acórdãos analisados invocaram a aplicação do princípio da precaução sem a utilização de 
e sem direção no Brasil. Frente a essa lacuna, emerge a necessidade de sintetizar os critérios que podem ser aplicados no âmbito de um caso concreto (i), assim como as medidas jurídicas que podem ser um efeito de sua utilização (ii).

\subsubsection{Critérios para aplicar o princípio da precaução a um caso concreto}

A interpretação do princípio da precaução poderia ser mais objetiva se os critérios ligados à sua aplicação servissem como parâmetro. Como indicado anteriormente, o leading case na delimitação de critérios para a aplicação do princípio no Brasil é o Recurso extraordinário ${ }^{90}$ 627189, decidido em 2016, com relação aos possíveis impactos dos campos eletromagnéticos na saúde e no meio ambiente. Tendo como base esse caso concreto e contribuições doutrinárias ${ }^{91}$, principalmente incluídas nesse livro, os seguintes critérios podem ser sintetizados com relação à possibilidade de aplicação do princípio: a) incerteza científica; b) a gravidade do risco; c) irreversibilidade do dano; d) a proporcionalidade ao nível de proteção escolhido; e) a razoabilidade da medida

O princípio da precaução pode ser aplicado, como fonte jurídica, em casos cujo risco esteja ligado à incerteza científica. Caso os efeitos do perigo sejam conhecidos pela ciência, ou seja, caso exista certeza quanto aos impactos da atividade, o princípio da prevenção deve ser aplicado(MACHADO, 2004). Ademais, para que o princípio da precaução seja aplicado, é também necessário que os riscos da atividade sejam graves ou irreversíveis, como é previsto na lei de crimes ambientais (Lei 9.605/1998), artigo 54, parágrafo 3. Esses critérios também foram previstos no artigo 15 da Declaração do Rio ${ }^{92}$. Tento em vista o Acórdão do STF de 2016, argumenta-se que o padrão adotado no Brasil, para a aplicação do princípio, é brando, flexível, pois exige que o dano seja grave

critérios específicos ou o fizeram sem a existência de uma incerteza científica. Somente em 30 acórdãos, ou seja, em aproximadamente $16 \%$ de todos os casos analisados, houve uma análise meritória da discussão em situações que foram consideradas como tendo invocado corretamente o princípio.

90 STF, RE 627189, decisão de 08 de junho de 2016.

91 EUR-Lex. Princípio de precaução. Disponível em: http://eur-lex.europa.eu/legal-content/PT/TXT/ ?uri=LEGISSUM:132042 . Acesso em: 25.07.2017.

92 Princípio 15 da Declaração do Rio/92: "Para que o ambiente seja protegido, serão aplicadas pelos Estados, de acordo com as suas capacidades, medidas preventivas. Onde existam ameaças de riscos sérios ou irreversíveis, não será utilizada a falta de certeza científica total como razão para o adiamento de medidas eficazes, em termos de custo, para evitar a degradação ambiental » 
e irreversível.

Dois outros critérios relevantes, que serão mais detalhados na análise das áreas temáticas, como no caso dos campos eletromagnéticos, são a proporcionalidade e a razoabilidade. Sabe-se que ambos são constantemente citados na jurisprudência, mas ainda há bastante incerteza quanto à sua operacionalizaçãa ${ }^{93}$. Entende-se que a proporcionalidade e a razoabilidade devem ser utilizadas para ponderar os efeitos do principio da precaução. Contudo, devem ser estabelecidos critérios mais objetivos para avaliar se uma decisão foi proporcional ou não, razoável ou não. $\mathrm{O}$ controle de legalidade é uma das formas de avaliar a proporcionalidade, o que foi feito pelo Acórdão de 2016 do STF e em diversos outros na análise do cumprimento das normas da Agência Reguladora. No entanto, a falta de critérios objetivos pode levar a conclusões completamente contraditórias e opostas do princípio da proporcionalidade, como pôde ser observado na análise do voto do ministro Dias Toffoli e do ministro Marco Aurélio no RE $627189^{94}$.

O papel do judiciário, na aplicação do princípio da precaução, está diretamente conectado ao controle de legalidade das atividades reguladas pelo poder executivo. A administração possui a capacidade técnica e a competência para aplicar, em matérias que são objeto de regulação, a gestão do risco. $\mathrm{O}$ entendimento da Comissão da União Européia sobre o tema auxilia na compreensão do passo a passo da gestão do risco. Como um primeiro passo, o princípio da precaução se aplica quando: se identifica efeitos potencialmente negativos, se avalia os dados científicos disponíveis e se avalia qual a extensão da incerteza científica. A partir daí, se o risco for elevado, medidas devem ser adotadas por atos jurídicos e deve ser ainda fomentada a investigação para o constante aprimoramento do conhecimento naquele risco. Desta feita, são diretrizes comuns à aplicação do princípio: uma avaliação científica do grau de incerteza, uma avaliação do risco e potenciais consequências e a participação das partes interessadas no estudo das medidas de precaução tão logo os resultados dos estudos são demonstrados ${ }^{95}$.

A partir da identificação desses critérios, as interpretações jurídicas para a aplicação do princípio devem tê-los como base. Ademais, as medidas substanciais e processuais utilizadas para implementar o princípio 93 Sobre a falta de critérios na utilização do princípio ver: (MASTRODI, 2014, p. 584).

94 Ver sobre o tema os julgados sobre campos eletromagnéticos.

95 EUR-Lex. Princípio de precaução. Disponível em: http://eur-lex.europa.eu/legal-content/PT/TXT/ ?uri=LEGISSUM:132042 . Acesso em: 25.07.2017. 
também devem estar baseadas em critérios objetivos.

\subsubsection{Critérios ligados às medidas jurídicas baseadas no princípio da precaução}

As medidas jurídicas materiais e processuais aplicáveis para reduzir/eliminar os riscos devem ser fundadas em critérios. Estes podem contribuir com a análise da proporcionalidade e da razoabilidade da medida.As seguintes medidas materiais podem resultar da sua aplicação: a exploração de alternativas a ações, inclusive a da não-ação; a exigência de mais estudos conclusivos sobre o tema por meio de reexame científico (precariedade da medida) (HAUTEREAU-BOUTONNET et al., 2015, p. 111); a exigência de estudo de impacto ambiental; a adequação da medida aos custos sociais e econômicos; a análise de medidas adotadas em casos similares ${ }^{96}$; o exame das vantagens e desvantagens resultantes da açãa ${ }^{97}$.

Quanto aos efeitos processuais, podem ser citados: a transferência do ônus da prova aos seus proponentes e não às vítimas ou possíveis vítimas; o emprego de processos democráticos de decisão e acompanhamento dessas ações, com destaque para o direito subjetivo ao consentimento informado.

Há casos na jurisprudência brasileira nos quais é possível encontrar referências a alguns critérios indicados mais acima ${ }^{98}$, principalmente no RE 627189, mas normalmente a menção aos critérios é feita de maneira pouco precisa e aleatória, sem um fio condutor e um "passo a passo"da subsunção da aplicação do princípio a critérios objetivos. Cada um desses critérios indicados será objeto de detalhamento nos artigos do livro. A despeito dessa abordagem posterior pormenorizada, três conclusões principais insurgem desses critérios: os limites do controle de legalidade feito pelo poder judiciário ao avaliar as medidas administrativas; o controle administrativo e judicial da tolerabilidade social quando aos riscos;a necessidade de adaptações das medidas judiciais e administrativas às inovações e evoluções científicas.

96 STF, RE 627189, decisão de 08 de junho de 2016.

97 EUR-Lex. Princípio de precaução. Disponível em: http://eur-lex.europa.eu/legal-content/PT/TXT/ ?uri=LEGISSUM:132042 . Acesso em: 25.07.2017.

98 STJ, Agravo Regimental, 1863/PR, decisão de 18 de fevereiro de 2009. Neste caso, a Corte menciona o princípio da proporcionalidade como critério, além da avaliação sobre não afetar de maneira importante a economia. Ou no julgado proferido pelo TRF da $4^{a}$ Região, Apelação cível $\mathrm{n}$. 2003.710401884-80/RS, decisão de 24 de março de 2010, em sentido contrário, no qual foi invocado o princípio da razoabilidade como elemento limitador da aplicação do princípio da precaução, para justificar a possibilidade de introdução de espécimes exóticas de peixes (tilápias do Nilo e "catfish") na bacia do Rio Uruguai, dado que o Poder Judiciário não poderia engessar para sempre a Administração, principalmente quando há dúvida científica e esta pode ser superada pela evolução da ciência. 
Com relação à primeira conclusão, o caso dos campos eletromagnéticos é emblemático, pois envolveu uma análise entre as os riscos da atividade e os parâmetros normatizados pelo poder executivo. A análise da legalidade se limitou ao parâmetro definido pela ANEEL para o risco ambiental, parâmetro esse baseado em estudos técnicos, científicos, discutidos em audiências públicas, cujo resultado está normatizado em regulamentos. A utilização de parâmetros científicos aproxima o princípio da precaução do princípio da prevenção. Quando há, diante do caso concreto, normas compiladoras de parâmetros a serem respeitados por uma determinada atividade, o princípio aplicável é o princípio da prevenção. A diferença principal, para a aplicação do princípio da precaução, está conectada à incerteza científica e à necessidade de adaptação de medidas mais flexíveis e abertas às inovações científicas sobre o tema. A depender da gravidade e da irreversibilidade do risco, a medida pode ser diferente para cada caso concreto.

Assim, a medida jurídica ordenada pelo poder administrativo ou judiciário, em um contexto de risco, pelo fundamento do princípio da precaução, deve ser proporcional ao nível do risco associado a uma dada atividade econômica. Tendo em vista esse aspecto, os juízes devem escolher a opção de regulação (proibição, realização de estudos prévios, controles mais rígidos, entre outros) estritamente necessária à proteção da saúde e do meio ambiente. A mera paralização da atividade não é providência, em algumas vezes, compatível com o princípio da precaução, mas sim com o princípio da prevenção. Ademais, as medidas jurídicas aplicadas devem ser economicamente viáveis. Essa lógica está explicitamente presente na formulação do princípio da precaução ${ }^{99}$ da Declaração do Rio. A interdição da construção de uma indústria ou de uma atividade de pesca em uma região desfavorecida do Brasil pode trazer consequências sociais aos indivíduos que dependem daquela atividade econômica.

No Brasil, o uso desordenado do princípio "in dubio pro natura" (BRYNER, 2015, p. 245-258) ${ }^{100}$ pode não levar em consideração questões sociais relevantes. Nesta seara podem ser referidos os casos envolvendo a

99 Princípio 15 da Declaração do Rio/92 : "Para que o ambiente seja protegido, serão aplicadas pelos Estados, de acordo com as suas capacidades, medidas preventivas. Onde existam ameaças de riscos sérios ou irreversíveis, não será utilizada a falta de certeza científica total como razão para o adiamento de medidas eficazes, em termos de custo, para evitar a degradação ambiental »

100 A jurisprudência brasileira, especificamente o STJ aceitou de modo amplo o princípio « in dubio pro natura », ver : STJ, Recurso Especia n. 1.198.727/MG, decisão de 14 de agosto de 2012 ; Resp n. 1.328.753/MG, decisão de 28 de maio de 2013 ; Resp n. 1.367.923/RJ, decisão de 27 de agosto de 2013. 
importação de crustáceos frutos de pesca selvagem na Argentina, dada a possibilidade de introdução de doenças virais na carcinicultura nacional ${ }^{101}$ e da redução da produção pesqueira em decorrência da construção de usinas hidroelétricas ${ }^{102}$. Nessas situações, a atividade pesqueira (industrial ou artesanal) e turística, fundamentais para algums regiões, podem ser desproporcionalmente afetadas ${ }^{103}$. Portanto, a participação social e a tolerabilidade dos riscos, para algumas regiões, pode ser diferente do que é tolerado em uma outra região, o que deve ser levado em consideração na análise caso a caso.

Deve existir um constante reexame dos fatos diante da atualização da investigação científica, dada a precariedade dos conhecimentos existentes no momento da prolação da medida judicial. Significa dizer que a medida liminar ou a sentença deveria ter um caráter transitório e poder ser objeto de revisões periódicas. Porém, como esta não é uma característica do processo civil brasileiro, dado que este deve caminhar para um desfecho, sua manifestação não pode ser compreendida pela Administração como final ou definitiva. Um ponto relevante do voto do relator no caso sobre campos eletromagnéticos julgado pelo STF em $2016^{104}$ foi indicar que a decisão poderia ser posteriormente alterada na medida em que avanços científicos exijam essa alteração.

Proferida uma decisão judicial, como nos casos já referidos dos OGMs ou dos campos eletromagnéticos, é dever da administração, seja durante o processo de licenciamento ou na fase de monitoramento, incorporar as inovações científicas, como elemento norteador de suas ações. Defende-se, então a existência de uma discricionariedade administrativa mitigada pela evolução científica e pelo monitoramento constante das medidas mitigadoras e compensatórias apresentadas no estudo de impacto ambiental. Essa característica é necessária justamente em razão da incerteza e guarda uma relação próxima com o fato de que a ciência está sempre em desenvolvimento.

No caso dos campos eletromagnéticos no STF, a atualização do conhecimento científico, resultado de audiência pública e

101 TRF 1ª Região, Agravo de instrumento n. 0036457-12.2013.4.01.0000, decisão de 06 de abril de 2016;

102 STJ, Agravo regimental no Agravo em Recurso especial n. 206.748, decisão de 27 de fevereiro de 2013.

103 STJ, Agravo regimental na suspensão de liminar e de sentença n. 1.302/PE, decisão de 03 de novembro de 2011.

104 STF, RE 627189, decisão de 08 de junho de 2016, p. 44. 
outros estudos que foram apurados pela agência, trouxe novo parâmetro de exposição 105 . Avaliou-se, por fim, que, na atualidade, "não existem fundamentos fáticos ou jurídicos a obrigar as concessionárias de energia elétrica a reduzir o campo eletromagnético das linhas de transmissão de energia elétrica abaixo do patamar legal fixado pela ANEEL"106. Mas, no entanto, o ministro relator ponderou que ${ }^{107}$, "é evidente que, no futuro, caso surjam efetivas e reais razões científicas e/ou políticas para a revisão do que se deliberou no âmbito normativo, o espaço para esses debates e a tomada de novas decisões há de ser respeitado".

Em suma, os critérios identificados são abordagens ou técnicas para lidar com o risco de dano irreversível na tomada de decisão e se tornam objetos de avaliação em uma análise de legalidade da ação possivelmente violadora do direito à saúde ou ambiental, sob exame no judiciário. Tem-se, assim, como técnicas fundamentadas no princípio da precaução medidas materiais e processuais, tais como: a exploração de alternativas a ações, inclusive a da não-ação; a exigência de mais estudos conclusivos sobre o tema por meio de reexame científico (precariedade da medida); a exigência de estudo de impacto ambiental; a adequação da medida aos custos sociais e econômicos; a análise de medidas adotadas em casos similares; o exame das vantagens e desvantagens resultantes da ação; a transferência do ônus da prova aos seus proponentes e não às vítimas ou possíveis vítimas; o emprego de processos democráticos de decisão e acompanhamento dessas ações, com destaque para o direito subjetivo ao consentimento informado.

\section{CONCLUSÕES}

A implementação do princípio da precaução no Brasil repercute na prevenção e na reparação de impactos ao meio ambiente, mas há limites acerca da precisão da natureza jurídica do princípio e de critérios que devem fundamentar a sua aplicação pelas autoridades administrativas

105 Trata-se da Resolução Normativa 616/2014 da Agência Nacional de Energia Elétrica (ANEEL). Sobre a alteração, nos termos da decisão: "A nova normativa resultou não só das conclusões extraídas da audiência pública efetivada pela ANEEL ( ${ }^{\circ}$ 97) no ano de 2013, instituída com vistas a colher subsídios e informações adicionais para o aprimoramento da anterior Resolução Normativa n 398/2010, como também levou em consideração os novos níveis de referência para campos magnéticos em $60 \mathrm{~Hz}$, os quais, ao final de 2010 , passaram de $83,33 \mu \mathrm{T}$ (microteslas) para $200 \mu \mathrm{T}$ (microteslas) para o público em geral, e de 416,67 $\mu \mathrm{T}$ (microteslas) para $1000 \mu \mathrm{T}$ (microteslas) para os trabalhadores pertinentes, conforme valores estabelecidos no documento oficial da ICNIRP”. STF, RE 627189, decisão de 08 de junho de 2016, p. 29.

106 STF, RE 627189, decisão de 08 de junho de 2016, p. 36.

107 STF, RE 627189, decisão de 08 de junho de 2016, p. 44. 
e pelos juízes. Três conclusões centrais podem ser ponderadas: 1) as autorizações administrativas das atividades potencialmente poluidoras podem ser modificadas pela implementação do princípio; 2) a inversão do ônus da prova é um efeito no contexto da flexibilização do nexo de causalidade da responsabilidade civil; 3) há limites na interpretação do princípio da precaução, ligados à precisão da sua natureza jurídica e da previsão de critérios mais objetivos para a sua aplicação.

As autorizações administrativas das atividades caracterizadas por um risco ao meio ambiente e à saúde podem ser modificadas com fundamento na interpretação do princípio da precaução. As modificações podem ser sintetizadas da seguinte maneira: 1) restrições temporárias; 2) anulação das autorizações; 3) compromissos com a continuação de pesquisas técnicas ou científicas sobre a matéria. Outras medidas, como a demanda de intervenção de um expert poderia ser objeto de medidas no judiciário. As razões que são normalmente objeto dessas decisões são a falta de estudo de impacto e a necessidade de estudos complementares. Um efeito interessante neste caso foi a elaboração de normas mais concretas sobre a utilização e a comercialização de OGMs, como um efeito das ações contra essa atividade.

A propósito das medidas ligadas à reparação dos danos, a inversão do ônus da prova foi objeto de decisões favoráveis à sua aplicação no contexto dos danos ambientais, o que é inovador na matéria. As críticas que podem ser feitas estão ligadas às condições para a sua implementação, considerando que é preciso uma segurança jurídica às partes que devem saber de maneira precisa quando o ônus da prova lhe é incumbido.

Com relação aos limites à implementação do princípio no Brasil, o artigo demonstrou que a realidade da sua aplicação é oposta ao contexto do direito internacional ambiental. Nesse contexto, os juízes e operadores do direito hesitam em aplicar as medidas que podem se originar do princípio da precaução, pois ele não é reconhecido como um princípio geral de direito internacional. Em contrapartida, no contexto do direito brasileiro, os juízes utilizam o princípio como uma regra de direito. Essa aplicação, contudo, é feita de maneira confusa, superficial e sem rigor acadêmico.

Para que esses limites possam ser superados, o artigo sintetizou os critérios que poderiam ser aplicados pelas autoridades administrativas e pelos juízes na interpretação do princípio. Quando o juiz deve aplicar o princípio ele deve verificar se os riscos associados a uma atividade são cientificamente desconhecidos e, assim, se os danos que resultam são 
graves ou irreversíveis. Na hipótese de uma resposta afirmativa a essas questões, deve ser feito um controle de legalidade, amparado nas normas infraconstitucionais existentes ou nos parâmetros científicos previstos e na tolerabilidade social relacionada aos atores envolvidos ativamente e passivamente aos riscos. Ademais, devem ser tomadas medidas proporcionais e razoáveis à gravidade do risco e às condições econômicas e sociais da implementação da prevenção ou reparação do dano. Essas medidas devem ser revisadas periodicamente, pois o conhecimento científico não é estático.

\section{REFERÊNCIAS}

ANTUNES, P. DE B. Princípio da precaução: breve análise de sua aplicação pelo Tribunal Regional Federal da $1^{a}$ região. maio 2007.

BIRNIE, P. W.; BOYLE, A. E.; REDGWELL, C. International law and the environment. 3rd ed ed. Oxford; New York: Oxford University Press, 2009.

BRYNER, N. S. In dubio pro natura: a principle for strengthening environmental rule of law $=$ In dubio pro natura: um princípio para o fortalecimento do estado de direito ambiental. 2015.

CZYZESKI, P. J. V. Análise jurisprudêncial dos princípios da prevenção e da precaução. Âmbito Jurídico, v. XIII, abr. 2010.

DAILlIER, P. et al. Droit international public: formation du droit, sujets, relations diplomatiques et consulaires, responsabilité, règlement des différends, maintien de la paix, espaces internationaux, relations économiques, environnement.8e édition ed. Paris: L.G.D.J., Lextenso éditions, 2009.

ELLIS, J. Overexploitation of a Valuable Resource? New Literature on the Precautionary Principle. European Journal of International Law, v. 17, $\mathrm{n}$. 2, p. 445-462, 1 abr. 2006. 
HAUTEREAU-BOUTONNET, M. Le principe de précaution en droit de la responsabilité civile. Paris: L.G.D.J, 2005.

HAUTEREAU-BOUTONNET, M. et al. L'influence $d u$ principe de précaution en droit de la responsabilité civile et pénale: regards francoquébécois. [s.l: s.n.].

KISS, A. C.; BEURIER, J.-P. Droit international de l'environnement.4. éd ed. Paris: Pedone, 2010.

LEITE, J. R. M.; AYALA, P. DE A. Dano ambiental: do individual ao coletivo extrapatrimonial: teoria e prática. 6 . ed., atual. e ampl. ed. São Paulo, SP, Brasil: Revista dos Tribunais, 2014.

MACHADO, P. A. L. Princípio da precaução no direito brasileiro e no direito internacional e comparado. In: VARELLA, M. D.; PLATIAU, A. F. B.; KISS, A. C. (Eds.). . Princípio da precaução. Coleção Direito ambiental em debate. Belo Horizonte: ESMPU : Del Rey, 2004.

MACHADO, P. A. L. Direito ambiental brasileiro. São Paulo, SP: Malheiros Editores, 2015.

MALJEAN-DUBOIS, S. Quel droit pour l'environnement? [s.1.] Hachette, 2008.

MASTRODI, J. Ponderação de direitos e proporcionalidade das decisões judiciais $=$ On balancing rights and proportionality of judicial decisions. Revista Direito GV, v. 10, n. 2, p. 577-596, dez. 2014.

MILARÉ, E. Direito do ambiente: doutrina, prática, jurisprudência, glossário. [s.1.] Editora Revista dos Tribunais, 2001.

MORAES, A. DE. Direito constitucional. São Paulo: Atlas, 2014.

NEGRÃO, P. G. Recurso especial: doutrina, jurisprudência, prática e legislação. São Paulo: Saraiva, 1997.

NOIVILLE, C. Ciência, Decisão, Ação: três observações em torno do princípio da precaução. In: VARELLA, M. D.; REDE LATINO- 
AMERICANA - EUROPÉIA SOBRE GOVERNO DOS RISCOS (Eds.). . Direito, sociedade e riscos: a sociedade contemporânea vista a partir da idéia de risco.Brasília: UNICEUB, 2006. p. 32-45.

PRIEUR, M. Droit de l'environnement, droit durable. Bruxelles: Bruylant, 2014.

SANDS, P. et al. Principles of international environmental law. Fourth edition ed. Cambridge; New York: Cambridge University Press, 2012.

Artigo recebido em: 26/02/2018. Artigo aceito em: 25/07/2018.

\section{Como citar este artigo (ABNT):}

OLVEIIRA, C. C.; FERREIRA, F. R.; MORAES, G. G. B. L.; BARBOSA, I. S. OS LIMITES DO PRINCÍPIO DA PRECAUÇÃO NAS DECISÕES JUDICIAIS BRASILEIRAS EM MATÉRIA AMBIENTAL. Veredas do Direito, Belo Horizonte, v. 15, n. 32, p. 327-356, ma./ago. 2018. Disponível em: $\quad<$ http://www.domhelder.edu.br/revista/index.php/veredas/article/ view/1252>. Acesso em: dia mês. ano. 